\title{
A new genus Shaitan elchini gen. et sp.n. (Aranei: Gnaphosidae) from Azerbaijan and Kazakhstan
}

\author{
Новый род Shaitan elchini gen. et sp.n. (Aranei: Gnaphosidae) \\ из Азербайджана и Казахстана
}

\author{
Mykola M. Kovblyuk ${ }^{1}$, Zoya A. Kastrygina ${ }^{1}$, Yuri M. Marusik ${ }^{2}$ \\ Н.М. Ковбцюк ${ }^{1}$, 3.А. Кастрыгина ${ }^{1}$ Ю.М. Марусик ${ }^{2}$

\begin{abstract}
Zoology Department, National Taurida V.I. Vernadsky University, Yaltinskaya street 4, Simferopol 95007, Ukraine. E-mail:
${ }^{1}$ Кафедра зоологии Таврического национального университета им. В.И.Вернадского, ул. Ялтинская 4, Симферополь 95007, Украина.

${ }^{2}$ Institute for Biological Problems of the North, RAS, Portovaya Str. 18, Magadan 685000, Russia. E-mail: yurmar@mail.ru.

${ }^{2}$ ИБПС ДВО РАН, Портовая 18 , Магадан 685000 , Россия.
\end{abstract} \\ kovblyuk@mail.ru; zoiac_21@mail.ru
}

KEY WORDS: Gnaphosidae, new genus, new species, Azerbaijan, Kazakhstan.

КЛЮЧЕВЫЕ СЛОВА: Gnaphosidae, новый род, новый вид, Азербайджан, Казахстан.

ABSTRACT. A new genus and a new species, Shaitan elchini gen. et sp.n., are described. The monotypic genus is characterized by stiff setae on the anterior surface of the cheliceral furrow, tarsal claws lacking teeth and the male copulatory organ lacking a median apophysis.

РЕЗЮМЕ. Описан новый род и вид Shaitan elchini gen. et sp.n. Он характеризуется жёсткими щетинками на передней поверхности желобка базального сегмента хелицер, коготками без зубчиков и отсутствием медианного отростка в копулятивном органе самца.

\section{Introduction}

Gnaphosidae Pocock, 1898 is a large family with 118 genera and 2134 species [Platnick, 2013]. Spiders of the family Gnaphosidae are distinct in their spinneret modification: anterior lateral spinnerets are enlarged, cylindrical (rather than conical) in shape and widely separated [Platnick, 1990]. However, there are some exceptions ("marginal" genera): Micaria Westring, 1851, Parasyrisca Schenkel, 1963, etc.

While studying gnaphosid spiders from Middle Asia and Caucasus we found an unknown species, which could not be placed in any known genus because of its unusual somatic morphology, combined with a unique structure of the copulatory organs. It has spinnerets corresponding to the figure of a generalized adult female gnaphosid (compare fig. 1 in Platnick [1990] and Figs 10, 16 in this paper). Comparison with all possible subfamilies and genera led us to the conclusion that it represents a new species and a new genus and can be placed more or less conventionally in the subfamily Drassodinae. The main goals of this paper are: 1) to describe the new genus and new species, 2) to discuss the relationships of the new genus and 3) to document the distribution of the new species.

\section{Material and Methods}

All specimens treated in this study are deposited in the Zoological Museum of the Moscow State University (ZMMU), Moscow, Russia (K.G. Mikhailov).

The following abbreviations are used in the text: RTA — retrolateral tibial apophysis; a — apical; d dorsal; $\mathrm{p}$ - prolateral; $\mathrm{r}$ - retrolateral; $\mathrm{v}$ - ventral spines.

Illustrations were made using reflected- and transmitted-light and SEM microscopes. Specimens were photographed using an Olympus Camedia C-520 camera attached to an Olympus SZX16 stereomicroscope at the Zoological Museum, University of Turku, Finland. The images were combined using "CombineZP" image stacking software. Photographs were taken in dishes of different sizes, with paraffin at the bottom. Holes of different sizes were made in the paraffin to keep the specimens in the correct position. SEM-microphotographs were made with a JEOL JSM-5200 in the Zoological Museum, University of Turku.

Coloration was described from specimens preserved in ethanol/water solution. All measurements are given in $\mathrm{mm}$. All scale bars equal $0.1 \mathrm{~mm}$.

\section{Taxonomy}

Shaitan gen $\mathbf{n}$.

Gnaphosidae Pocock, 1898

TYPE SPECIES. Shaitan elchini sp.n. 

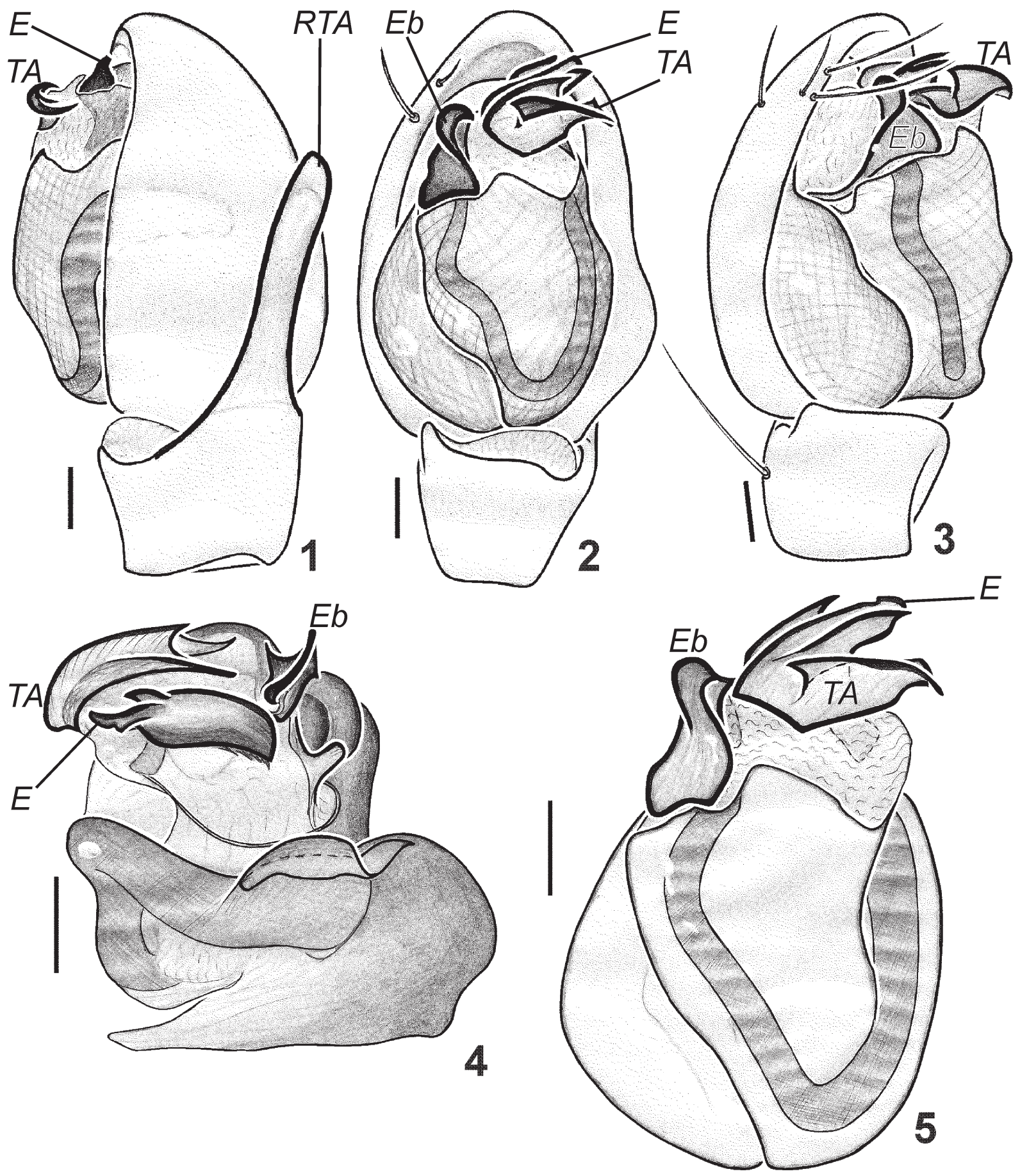

Figs 1-5. Males of Shaitan elchini gen. et sp.n.: 1 - palp, retrolateral view; 2 - palp, ventral view; 3 - palp, prolateral view; 4 bulbus, dorso-apical view; 5 - bulbus, ventral view. Abbreviations: $E$ - embolus; $E b-$ embolar base; $R T A-$ retrolateral tibial apophysis; $T A$ — terminal apophysis.

Рис. 1-5. Самцы Shaitan elchini gen. et sp.n.: 1 - пальпа, ретролатерально; 2 - пальпа, вентрально; 3 - пальпа, пролатерально; 4 - бульбус, дорсо-апикально; 5 - бульбус, вентрально. Сокращения: $E$ - эмболюс; Eb - основание эмболюса; RTA ретролатеральный отросток голени; $T A$ - терминальный отросток.

ETYMOLOGY. The generic name is derived from Arab and Russian "shaitan" meaning "devil, deuce". Masculine in gender.

DIAGNOSIS. Differs from all gnaphosids by having stiff setae on the anterior surface of the cheliceral furrow (Figs 9, 15, 21), tarsal claws lacking teeth (Fig. 23 ) and in lacking a median apophysis in the bulbus (Figs 2, 5, 18, 24-27).

DESCRIPTION. Medium-sized (total length 4.25.4). Carapace ovoid, yellow, without dark margins or 

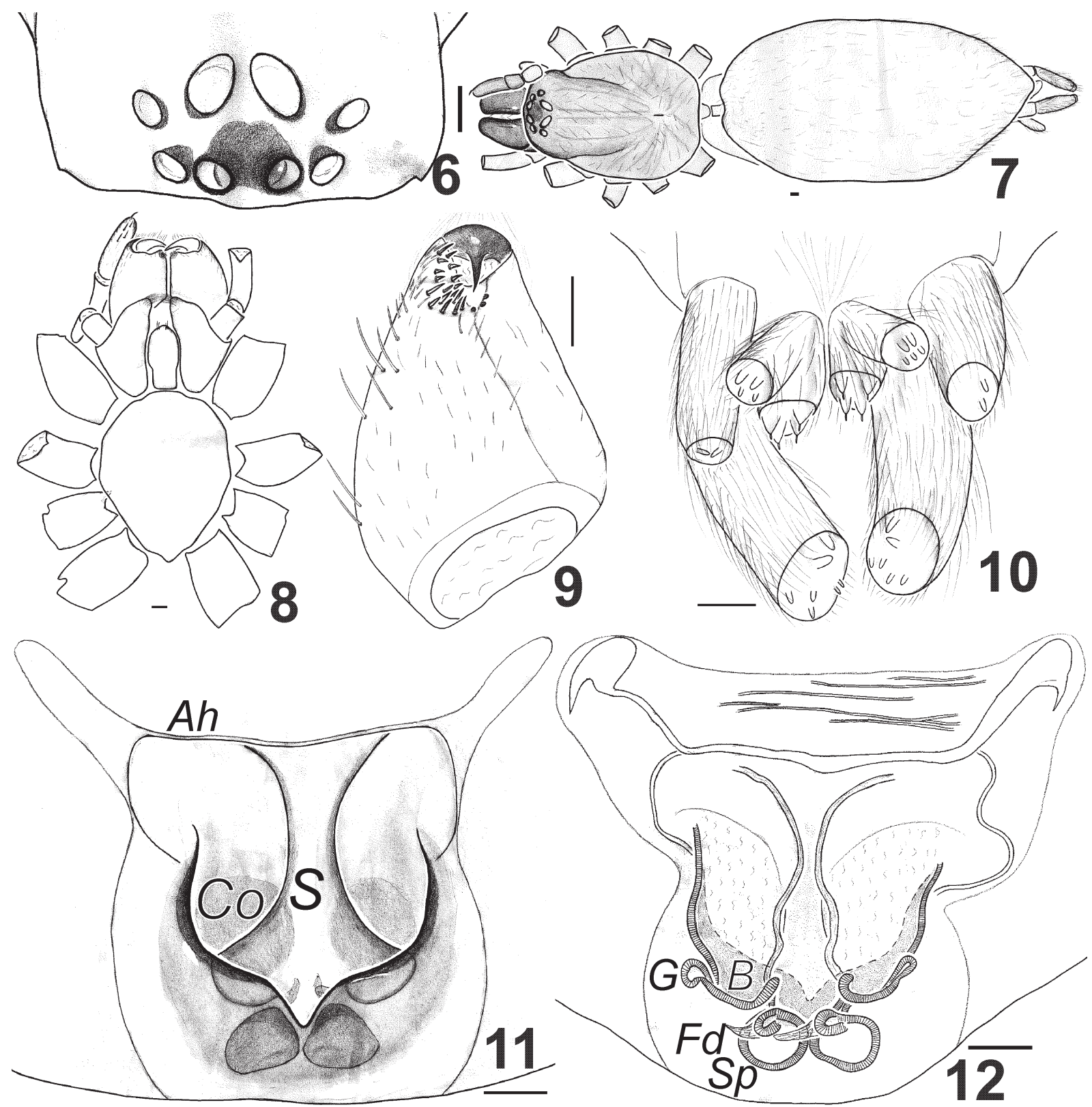

Figs 6-12. Females of Shaitan elchini gen. et sp.n.: 6- eyes, dorsal view; 7 - general appearance, dorsal view; 8 - prosoma, ventral view; 9 - chelicera, mesal view; 10 - spinnerets, ventral view; 11 - epigyne, ventral view; 12 - epigyne, dorsal view. Abbreviations: $A h$ - anterior hood; $B$ - copulatory bursa; $C o-$ copulatory opening; $F d$ - fertilization duct; $S$ - septum; $G$ - gland; $S p-$ spematheca.

Pис. 6-12. Самка Shaitan elchini gen. et sp.n.: 6 - глаза, дорсально; 7 - габитус, дорсально; 8 - просома, вентрально; 9 хелицера, изнутри; 10 - паутинные бородавки, вентрально; 11 - эпигина, вентрально; 12 - эпигина, дорсально. Сокращения: $A h$ - передний карман эпигины; $B$ - копулятивная бурса; $C o-$ копулятивное отверстие; $F d-$ оплодотворительный канал; $S-$ септум; $G$ - железа; $S p$ - сперматека.

pattern, but with slightly darkened eye region and with a well developed brown median groove (Fig. 13). Chelicerae, endites, labium and palps light brown. Legs yellow coloured like the carapace, only tarsi I-II slightly darker, light brown. Posterior median eyes largest (Figs 14, 22). All eyes closely situated, separated by less then their diameter (Figs 14, 22). Sternum ovoid, obtuse posteriorly, projecting between coxae IV. Abdo- men lighter than carapace, white-yellow. Scutum absent.

Chelicerae with two posterior teeth and one anterior tooth. Cheliceral furrow on the anterior surface with bizarre stiff setae (Figs 15, 21).

Tarsi with well-developed scopula of strong bristles and with claw tufts (Fig. 23). Tarsal claws without teeth (Fig. 23). 


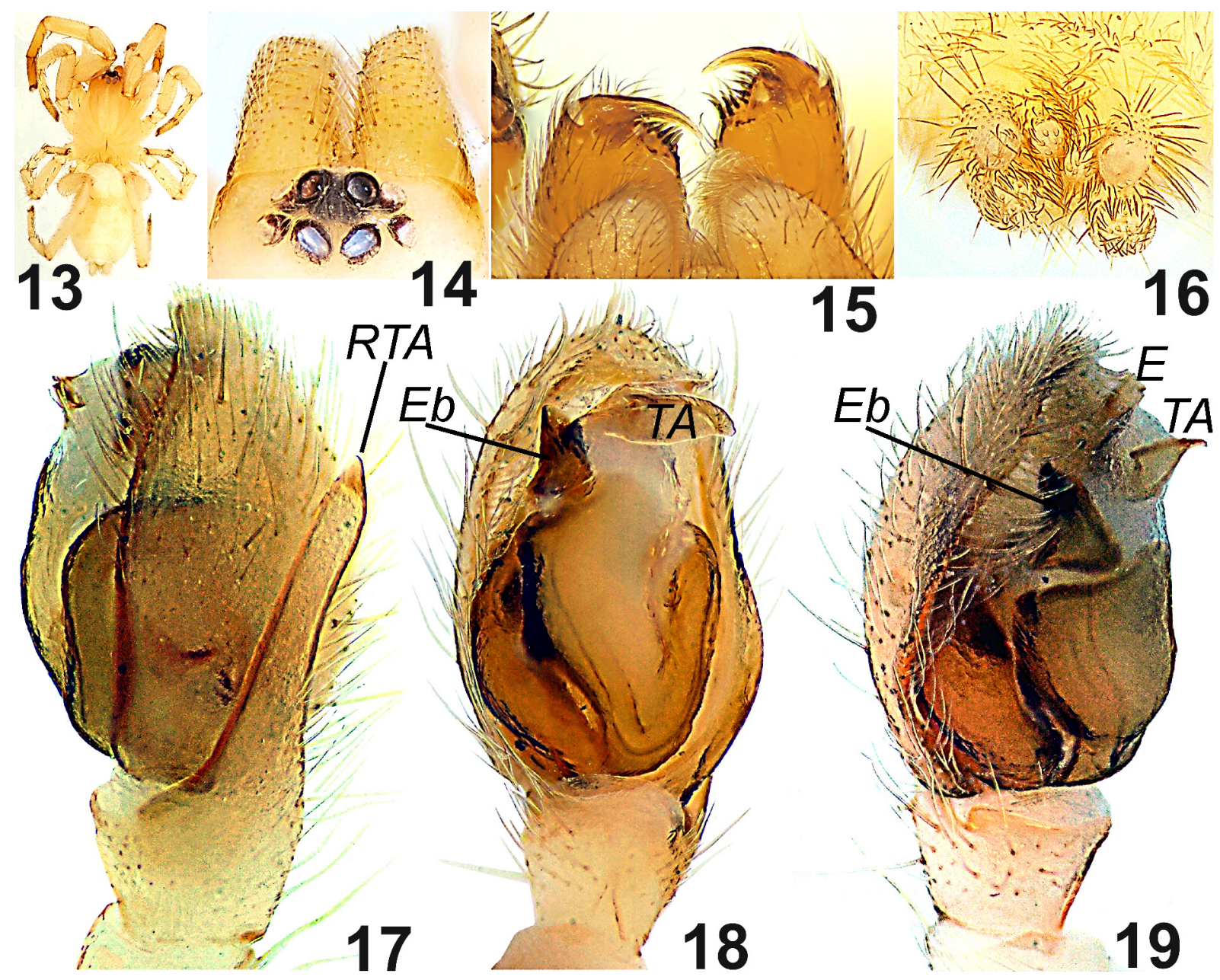

Figs 13-19. Males of Shaitan elchini gen. et sp.n.: 13 - general appearance, dorsal view; 14 - eyes, dorsal view; 15 - chelicerae, ventral view; 16 - spinnerets, ventral view; 17 - palp, retrolateral view; 18 - palp, ventral view; 19 - palp, prolateral view. Abbreviations: $E$ - embolus; $E b$ - embolar base; $R T A$ - retrolateral tibial apophysis; $T A$ - terminal apophysis.

Рис. 13-19. Самцы Shaitan elchini gen. et sp.n.: 13 - габитус, дорсально; 14 - глаза, дорсально; 15 - хелицеры, вентрально; 16 - паутинные бородавки, вентрально; 17 - пальпа, ретролатерально; 18 - пальпа, вентрально; 19 - пальпа, пролатерально. Сокращения: $E$ - эмболюс; $E b$ - основание эмболюса; $R T A$ - ретролатеральный отросток голени; $T A$ - терминальный отросток.

Tibial apophysis long and thin, twice longer than tibia and almost as long as cymbium; median apophysis absent; upper part of bulbus is similar to that in Haplodrassus Chamberlin, 1922 with well developed complex terminal apophysis $(T A)$; embolus $(E)$ short and with the robust base $(E b)$ (Figs 1-5, 17-19, 2429). Conformation of epigyne is similar to that in Haplodrassus, with a wide anterior hood $(A h)$, well-developed copulatory bursa $(B)$, and a septum $(S)$ between large copulatory openings (Co) (Figs 11-12).

COMPOSITION. Type species only.

\section{Shaitan elchini sp.n.}

Figs 1-29.

TYPE MATERIAL. Holotype $\sigma^{\top}$ (ZMMU), KAZAKHSTAN, South Kazakhstan (=Jambyl) Area, Karatau Mt. Range, 20 km N from Dzhambul (=Taraz), 16.05.1991 (S.V. Ovchinnikov).
Paratypes: 1 ( ${ }^{7}$ (ZMMU), Kazakhstan, Aktolagay, Akkuduk, 711.05.2004 (K.E. Dovgailo \& I.A. Solodovnikov); 1 q (ZMMU) from AZERBAIJAN, Apsheron, environs of Baku, Bakinskie Ushy Mt., 28.04.2000 (E.F. Huseynov).

NOTE. Males from Kazakhstan and the female from Azerbaijan are conspecific in our opinion, because they are of identical general appearance, and both have the specific stiff setae on the anterior surface of the cheliceral furrow, similar eyes, and are of similar size.

ETYMOLOGY. The specific name is a patronym in honour of our friend and colleague Elchin Fizuli oglu Huseynov (Baku, Azerbaijan), who made a great contribution to the study of faunistics, systematics and ethology of Caucasian spiders, and who collected the paratype of the new species.

DIAGNOSIS. As for genus.

DESCRIPTION. Male. Measurements ( $\sigma^{7}$ holotype): total length 4.2 ; carapace 2.0 long, 1.5 wide; 

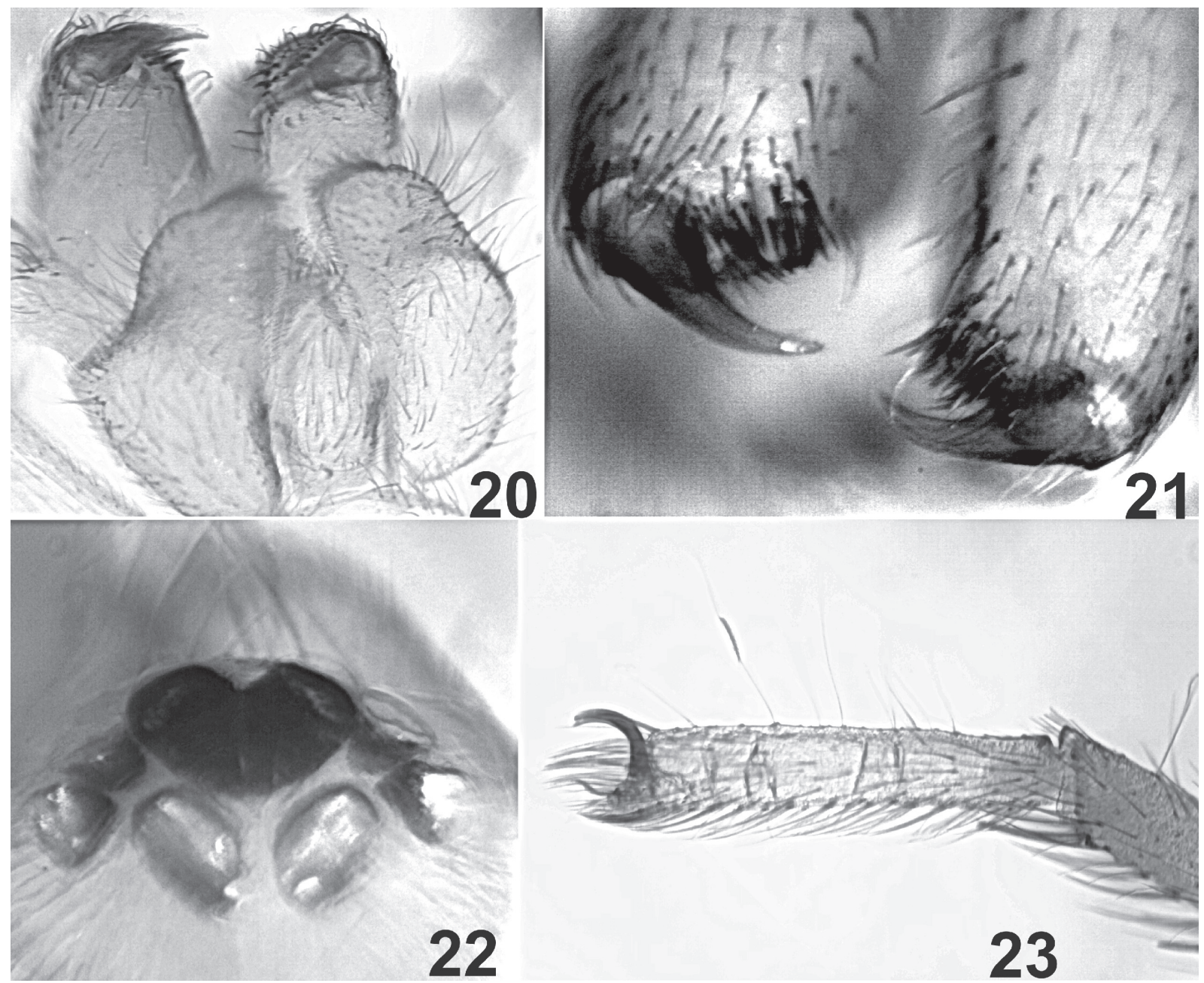

Figs 20-23. Males of Shaitan elchini gen. et sp.n.: 20 - chelicerae and endites, ventral view; 21 - chelicera, anterior view; $22-$ eyes, dorsal view; 23 - tarsus IV, retrolateral view.

Рис. 20-23. Самцы Shaitan elchini gen. et sp.n.: 20 - хелицеры и эндиты, вентрально; 21 - хелицера, спереди; 22 - глаза, дорсально; 23 - лапка IV, ретролатерально.

femur II 1.3 long. Leg spination. Femur: I - d 1-1, p 1; II - d 1-1, p 1; III - d 1-1, r 1; IV - d 1-1, r 1 or 1-1. Tibia: I — v 1(r)-1(p)-2(a); II — v 1(p)-1(p)-2(a); III $\mathrm{d} 1, \mathrm{p} 1$ or $2, \mathrm{v} 2-2-2(\mathrm{a})$; IV - p $1, \mathrm{r} 2, \mathrm{v} 2-2-2(\mathrm{a})$. Metatarsus: I - p 1-1-1, v 2-2-2a; II - p 1(a), v 2-22(a); III - p 2-2(a), r 2(a), v 2-1(p)-2(a); IV - r 1(a), v 2-2-2(a).

Palp as in Figs 1-5, 17-19, 24-29; femur and patella unmodified; tibia with long and thin apophysis $(R T A)$; RTA two times longer than the tibia and almost equal in length to cymbium; cymbium unmodified, without tapering tip; subtegulum large; terminal part of bulbus with large and complex embolic division composed of complex terminal apophysis $(T A)$ and complex embolus $(E)$; terminal apophysis - elongated blade with a short sharpened ventral lobe; embolus short and strong, with robust and dark base of embolus $(E b)$, hidden by terminal apophysis. Median apophysis and conductor absent.

Female. Measurements: total length 5.4; carapace 1.9 long, 1.3 wide; femur II 0.8 long. Coloration, eyes, chelicerae - as in male (Figs 6-9). Leg spination. Tibia: I — v 1(r)-2(a); II — v 1(a); III — v 1-2(a); IV — v 2-2-2(a). Metatarsus: I - v 2-2-2a; II - v 2-2-2(a); III - p 2, r 1, v 1-1-2(a); IV - p 1, v 1-1-2(a).

Epigyne as in Figs 11-12; without scape, but with wide anterior hood $(A h)$ with small lateral pockets similar to that in some Haplodrassus Chamberlin, 1922; fovea with strong septum $(S)$ and well developed lateral pockets; copulatory openings ( $\mathrm{Co}$ ) large; spermathecae $(S p)$ small, globular, slightly overlapping; glands $(G)$ and bursa copulatorix $(B)$ are well developed.

DISTRIBUTION. Azerbaijan and Kazakhstan (Map 1).

\section{Discussion}

Traditionally, the family Gnaphosidae is subdivided into 8 extant subfamilies (Drassodinae, Echeminae, Gnaphosinae, Hemicloeinae, Herpyllinae, Laroniinae, Micariinae, Zelotinae) and one extinct subfamily (Eo- 


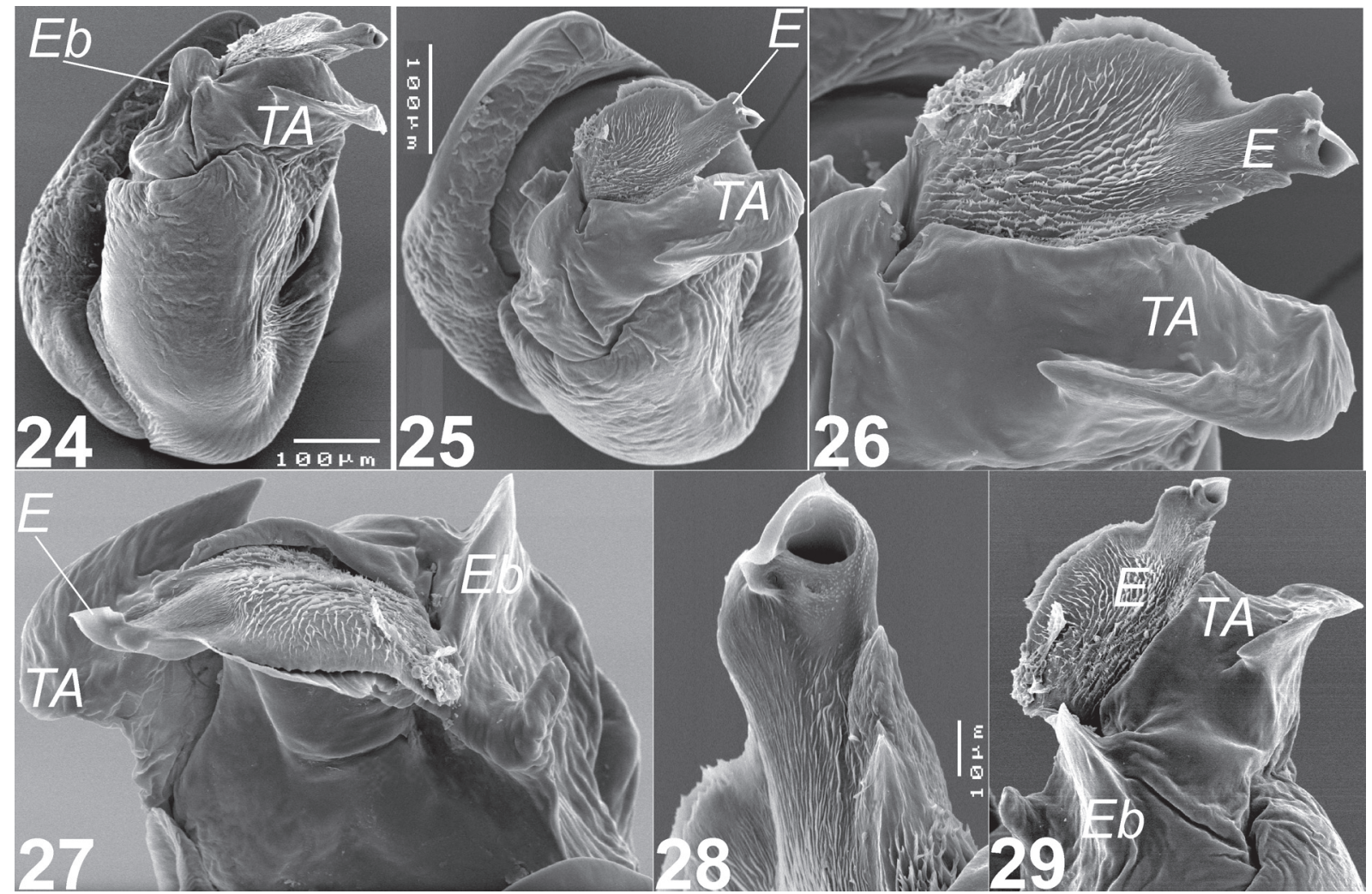

Figs 24-29. Male palp of Shaitan elchini gen. et sp.n.: 24 - bulbus, ventral view; 25 — bulbus, ventro-apical view; 26 - bulbus, apical view; 27 - bulbus, dorso-apical view; 28 - tip of embolus, retrolateral-apical view; 29 - bulbus, prolateral-apical view. Abbreviations: $E$ - embolus; $E b$ - embolar base; $T A$ - terminal apophysis.

Рис. 24-29. Пальпа самца Shaitan elchini gen. et sp.n.: 24 - бульбус, вентрально; 25 - бульбус, вентро-апикально; 26 бульбус, апикально; 27 - бульбус, дорсо-апикально; 28 - кончик эмболюса, ретролатерально-апикально; 29 - бульбус, пролатерально-апикально. Сокращения: $E$ - эмболюс; $E b$ - основание эмболюса; $T A$ - терминальный отросток.

mactatorinae) [Ubick et al., 2005; Jocqué \& DippenaarSchoeman, 2006; Wunderlich, 2011]. Gnaphosid subfamilies are mainly distinguished by somatic characters. Echeminae are characterized by chelicerae without serrated keels and lobes, lack of a metatarsal preening comb, procurved posterior eye row, dentate tarsal claws, long embolus originating on prolateral side of tegulum [Dippenaar-Schoeman \& Jocqué, 1997]. Gnaphosinae are recognized by rounded palpal endites and a cheliceral retromargin with structures varying from a distinct, serrated keel to translucent laminae [DippenaarSchoeman \& Jocqué, 1997]. Hemicloeinae have a sclerotized ring on the posterior lateral spinnerets and a very flat and thin body [Murphy, 2007]. In Herpyllinae the abdomen and legs are usually with a contrasting black and white pattern and a median apophysis is absent [Ubick et al., 2005; Wunderlich, 2011]. Laroniinae are recognized by the presence of one or more laminae on the retromargin of the chelicerae, an abdomen with a clear contrasting pattern, and a male palp with a long and coiled embolus [Dippenaar-Schoeman \& Jocqué, 1997]. Micariinae can be recognized by their small anterior lateral spinnerets and an ant-like body, often with iridescent scales on both carapace and abdomen [Dippenaar-Schoeman \& Jocqué, 1997]. Zelo- tinae have metatarsi III and/or IV with a preening comb [Dippenaar-Schoeman \& Jocqué, 1997]. Eumactorinae are described from Baltic amber and are characterized by major ampullate gland spigots on anterior lateral spinnerets with a large and robust sclerotized base [Wunderlich, 2011]. The subfamily Drassodinae is not well defined and is used as a "waste-basket" for groups which do not fit in elsewhere [Platnick, 1990; Dippenaar-Schoeman \& Jocque, 1997].

Based on the chelicerae without any lobes, keels and laminae, the new genus cannot be placed into Gnaphosinae or Laroniinae. In lacking preening combs on metatarsi III and/or IV and a male abdominal scutum it differs from Zelotinae. By having an unmodified body shape it differs from Hemicloeinae and Micariinae. By having unmodified (basal for gnaphosids) spinnerets, it differs from Eumactorinae, Hemicloeinae and Micariinae. Its short embolus differs from those in Echeminae and Laroniinae. Based on the similar conformation of the embolus, terminal apophysis and RTA, we placed the new genus in Drassodinae, although tarsal claws without teeth are unique for the family.

The male palp and epigyne of the new genus are somewhat similar to those in Haplodrassus. Both genera have a similarly shaped cymbium (rounded not 
tapering at the tip), a large subtegulum, the embolus with a large opening; but the new genus has no median apophysis, which is present in all Drassodinae, it also lacks a conductor. The palp in Shaitan gen.n. and in Haplodrassus has a complex embolus (=embolic division) with a flat embolus proper and a basal outgrowth (=terminal apophysis). The connection between the embolus and the terminal apophysis in Haplodrassus is very distinct, although in the new genus it is clearly visible only in SEM figures (Figs 24-26). The basal part of the terminal apophysis is very thin and transparent. The epigynes in two genera are more similar and have well-developed lateral pockets, small round spermathecae and glands.

It is very likely that claws lacking teeth and stiff setae on the chelicerae are adaptations to life in sandy habitats. Possibly the stiff setae on the chelicerae are used for digging, as in representatives of the family Ammoxenidae [Dippenaar-Schoeman \& Jocqué, 1997]. The cluster of stiff setae on the anteromedian surface of the chelicerae in Shaitan gen.n. is similar (convergent) to that one in Trachyzelotes Lohmander, 1944 (but not identical). Possibly such stiff setae are used for digging in both cases.

ACKNOWLEDGEMENTS. We sincerely thank J. Wunderlich and V.I Ovtsharenko for discussion about the possible relationships of this new genus. We also thank S. Koponen (Turku, Finland) who arranged our stay in Turku and provided lab equipment (SEM and digital camera attached to a microscope). Material used for this study was provided by E.F. Huseynov (Baku, Azerbaijan) and E.M. Zhukovets (Minsk, Belarus). We are deeply obliged to K.E. Dovgailo, E.F. Huseynov, late S.V. Ovchinnikov, I.A. Solodovnikov for collecting spider specimens. We thank P.E. Gol'din (Simferopol) and David Penney (Manchester) for improving the English of the earlier and final drafts. Special thanks go to Mikhail Omelko (Vladivostok, Russia), Christo Deltshev (Sofia, Bulgaria) and Feng Zhang (Hebei, China) for reviewing the final draft of the manuscript. This project was supported in part by the Russian Foundation for Fundamental Research (grants \#\# 11-04-01716 and 12-04-01548) and by the Karadag Nature Reserve.

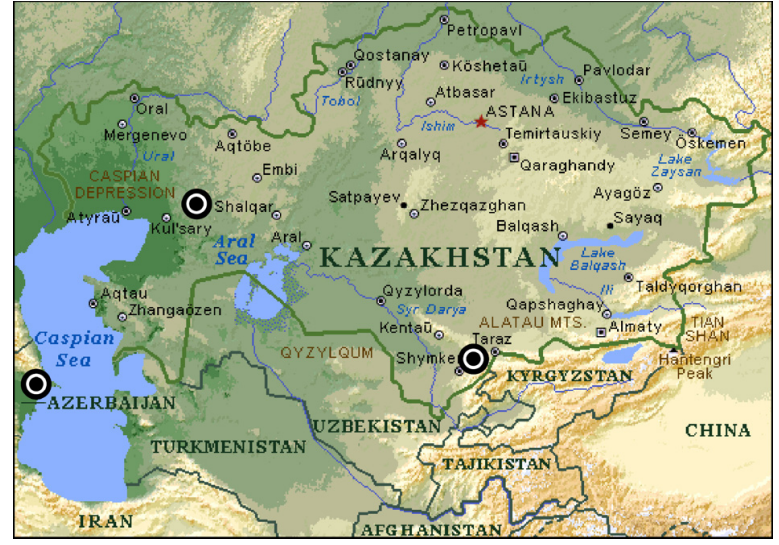

Map 1. Localities of studied specimens of Shaitan elchini gen.n. et sp.n.

Карта 1. Места сбора изученных экземпляров Shaitan elchini gen.n. et sp.n.

\section{References}

Dippenaar-Schoeman A.S., Jocqué R. 1997. African Spiders: An Identification Manual. Plant Protection Research Institute Handbook. No.9. Pretoria: Plant Protection Research Institute. 392 pp.

Jocqué R., Dippenaar-Schoeman A.S. 2006. Spider Families of the World. Tervuren: Musee Royal de l'Afrique Centrale. 336 pp.

Murphy J. 2007. Gnaphosid genera of the world. British Arachnological Society, St Neots, Cambs. 2 volumes. Vol.1 (text). P.ixii, 1-92. Vol.2 (plates). P.i-ii, 93-605.

Platnick N.I. 1990. Spinneret morphology and the phylogeny of ground spiders (Araneae, Gnaphosoidea) // American Museum Novitates. No. 2978. 42 pp.

Platnick N.I. 2013. The world spider catalog, version 13.5. American Museum of Natural History, online at http:// research.amnh.org/iz/spiders/catalog.

Ubick D., Paquin P., Cushing P.E., Roth V. 2005. Spiders of North America: an identification manual. American Arachnological Society. 377 pp.

Wunderlich J. 2011. Taxonomy of extant and fossil (Eocene) European ground spiders of the family Gnaphosidae (Araneae), with a key to the genera, and descriptions of new taxa // Beiträge zur Araneologie. Vol.6. P.19-97.

Responsible editor K.G. Mikhailov 